\title{
Psihosocijalni aspekti oboljenja od raka dojke kod mladih žena
}

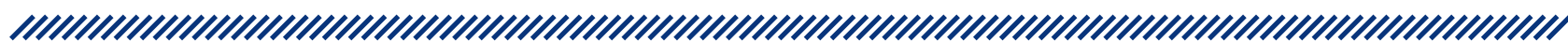

\author{
1 Anita Džombić \\ 1 Centar za socijalnu skrb Ivanić-Grad
}

\section{Sažetak}

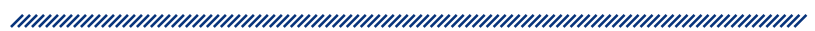

Psihosocijalni aspekti oboljenja od raka dojke kod mladih žena ostvaruju se unutar specifične razvojne dobi u kojoj se one nalaze. Oboljenje od raka dojke kod mladih, za razliku od starijih žena, povezano je ponajprije s izazovima prilagodbe u područjima radne karijere, partnerstva, obiteljskih planova, brige o osiguranju skrbi za djecu, reproduktivnog zdravlja, seksualnosti te slike o vlastitom tijelu. lako u psihoonkološkoj literaturi izostaje jedinstvena definicija ove populacije, riječ je o ženama u fertilnoj, predmenopauzalnoj dobi, s gornjom kronološkom granicom do 50 godina. Dosadašnje empirijske spoznaje navode da se one percipiraju „premladima za preuzimanje uloge bolesnice”, imaju veće poteškoće psihosocijalne prilagodbe na oboljenje i nižu kvalitetu života. Imaju potrebe za cjelovitom i pravodobnom informacijskom podrškom, dok im je diskusija o reproduktivnom zdravlju, prenatalnoj edukaciji i seksualnosti od posebne važnosti na samom početku tretmana. Oboljele upućuju na nedovoljan broj programa podrške namijenjenih ovoj populaciji i iskazuju spremnost na sudjelovanje u vršnjačkim mrežama podrške. U skladu s navedeni, u radu se nastoji ukazati na specifičnosti psihosocijalnih potreba i teškoća koje ove mlade žene imaju po oboljenju od raka dojke.
Ključne riječi: rak dojke, psihosocijalni aspekti, mlade žene

Datum primitka: 21.05.2018.

Datum prihvaćanja: 07.10.2018.

DOI: $10.24141 / 1 / 5 / 1 / 6$

Adresa za dopisivanje: Anita Džombić, mag. act. soc. Centar za socijalnu skrb Ivanić-Grad Franje Jurinca 6, Ivanić-Grad tel.: 0038512882301

e-pošta: anita.dzombic@gmail.com 


\section{Uvod}

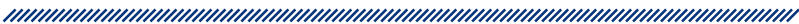

Oboljenje od raka dojke mijenja psihički, emocionalni i socijalni svijet žena, prijetnja je životu i očuvanju cjelokupnog integriteta. Rak dojke najčešće je maligno oboljenje žena u svijetu. Dosadašnje empirijske spoznaje o medicinskom tretmanu liječenja, biopsihosocijalnim aspektima bolesti, kao i višestrukim te kompleksnim izazovima s kojima se žene suočavaju upućuju na važnost sagledavanja raka dojke ne samo kao perzistirajućeg javnozdravstvenog problema nego područja od stalnog empirijskog interesa i profesionalne prakse pomažućih djelatnika - psihijatara, psihologa, socijalnih radnika i dr.

Postignuti znatni pomaci u liječenju povećali su stope preživljenja, i to primarno kroz povećanu svijest o činiteljima rizika, organiziranu provedbu mamografskih pregleda, rano otkrivanje i uspješniju kombinaciju tretmana (kemoterapiju, radioterapiju, hormonalnu terapiju, operacijske zahvate). ${ }^{1,2} \mathrm{U}$ skladu s time izgledno je petogodišnje preživljenje u $98,9 \%$ slučajeva lokaliziranog raka dojke, odnosno $85,2 \%$ regionalnog oboljenja. ${ }^{3}$ Prema podacima Registra za rak, ${ }^{4}$ u 2015. godini ukupno je bilo 2748 novooboljelih žena, od kojih je 1038 umrlo. Incidencija raka dojke raste s dobi i najveći broj oboljelih nalazimo u dobi od šezdesete do sedamdesete godine života, ${ }^{4}$ no ipak, zbog dobne i razvojne specifičnosti, posebnu istraživačku pažnju zadobiva populacija mladih oboljelih žena. Prilikom pojmovnog određenja „mladih žena” u psihoonkološkoj literaturi izostaje jedinstvena definicija i prisutan je varijabilitet u određenju kronološke dobi sudionica (do 40, 45 ili 50 godina). Važniji kriterij od gornje kronološke granice odnosi se na razvojne zadatke pred kojima se mlade žene nalaze. ${ }^{5}$

Istraživački se interes, u ovom području psihoonkologije, primarno oblikovao oko tema kvalitete života mladih žena, ${ }^{6,7}$ psihosocijalnih potreba, ${ }^{8-11}$ partnerstva i obiteljskog života, ${ }^{12-14}$ reproduktivnog zdravlja, ${ }^{15-18}$ seksualnosti i slike o vlastitom tijelu, ${ }^{19-22}$ socijalne podrške, ${ }^{23-26} \mathrm{i} \mathrm{dr}$. Namjera je ovog rada, na temelju dostupnih empirijskih spoznaja, ukazati na specifičnosti psihosocijalnih teškoća s kojima se susreću mlade žene uslijed oboljenja te pridonijeti boljem razumijevanju njihovih potreba tijekom aktivnog tretmana liječenja.

\section{Rak dojke kod mladih žena kao društveni konstrukt: Od interpretacije etiologije bolesti do društvenih očekivanja}

Postojeći korpus empirijskog (medicinskog) znanja nedovoljno raspolaže saznanjima o etiologiji razvoja raka dojke. Biomedicinski dosezi u pogledu nastanka i detaljnih mehanizama razvoja bolesti uglavnom se formiraju oko najvažnijih činitelja koji povećavaju rizik oboljenja. U procesima društvene konstrukcije navedeno može predstavljati povoljnu osnovu za proizvoljne i varijabilne interpretacije nastanka i razvitka bolesti.

Društveni diskurs, posredovan primarno kroz medijski sadržaj, u Americi je tako povećanu incidenciju raka dojke u prethodnim desetljećima prošlog stoljeća interpretirao u razmjerima epidemije, od koje, u najvećem broju, obolijevaju mlade žene. Analizom sadržaja 228 popularnih časopisa u periodu od 1980. do 1995. utvrđeno je da je povećanje incidencije raka dojke pojašnjeno mističnom, neočekivanom epidemijom, čijem nastanku i širenju pridonose specifična ponašanja mladih žena, i to odgađanje biološkog majčinstva, zadržavanje statusa nerotkinja, uporaba oralnih kontraceptiva i inducirani pobačaj. ${ }^{27}$ Pritom su nedovoljno isticani ili u cijelosti zanemareni doprinosi ranog otkrivanja raka dojke u okviru organiziranih preventivnih pregleda, poboljšana kvaliteta terapijskih postupaka i znanstveno utemeljeni činitelji rizika. Činitelji su rizika dob, prva menstruacija prije 12 . godine, menopauza poslije 50 . godine, nerađanje ili rađanje poslije 30 . godine, pretilost, biopsijski nalaz (epitelne hiperplazije ili atipije), raniji nalaz karcinoma te postojanje oboljelih srodnica po ženskoj liniji. Povećanom riziku oboljenja pridonose i nezdrave životne navike, poput nedovoljnog kretanja i nezdrave prehrane (višak masnoća, šećera, brza hrana), pušenja, pretjerane konzumacije alkohola te izloženost stresu i ionizirajućem zračenju. ${ }^{28} \mathrm{~S}$ druge strane, promocija mamografskih kampanja u prvom redu namijenjenih ženama starijima od 50 godina, $u$ javnom diskursu, pridonijela je percepciji o raku dojke kao bolesti od koje obolijevaju isključivo starije osobe, dok je u pogledu strategija nošenja $s$ bolesti mladim ženama nerealno pripisivana hrabrost $\mathrm{i}$ požrtvovnost. ${ }^{5}$ Osim necjelovitog portretiranja populacije oboljelih i pristranog, neznanstvenog objašnjavanja etiologije bolesti, i društvena očekivanja od mladih žena u pogledu roditeljstva, partnerstva i slike o tijelu mogu dodatno otežati proces prilagodbe na rak dojke i prihvaćanje promijenjenog dijela svojeg identiteta uslijed oboljenja. 0 navedenim aspektima detaljnije je pojašnjeno u nastavku. 


\section{Oboljeti od raka dojke u predmenopauzalnoj dobi: Koje razvojne zadatke oboljenje dovodi u pitanje?}

Rak dojke u ovoj dobnoj skupini tendira biti dijagnosticiran u kasnijem stadiju bolesti, ima agresivnija obilježja, veća je vjerojatnost lokalnih recidiva i niži su pozitivni klinički ishodi u odnosu na starije žene. ${ }^{29-31} \mathrm{U}$ psihosocijalnom kontekstu, s obzirom na to da konkretni biološ$\mathrm{ki}$, osobni i socijalni životni ciljevi te zadaci predstavljaju važnu determinantu prilagodbe, ista dijagnoza kod žene u dobi od trideset $\mathrm{i}$ one $\mathrm{u}$ dobi od sedamdeset godina znači vrlo različit izazov razvojnim zadacima. ${ }^{32}$ Utjecaj oboljenja ovim će mladim ženama, za razliku od starijih, značiti ponajprije izazove u područjima obrazovnih planova, radne karijere, partnerstva, obiteljskih planova i brige o osiguranju skrbi za djecu, reproduktivnog zdravlja, seksualnosti i slike o vlastitom tijelu. ${ }^{9,30,33-34}$

U industrijaliziranim zemljama $25 \%$ mladih žena obolijeva od raka dojke. ${ }^{34} \mathrm{U}$ Hrvatskoj je udio oboljelih te dobi $17 \%$, odnosno 466 novooboljelih u 2015. godini (HZJZ 2018). ${ }^{4}$ Mlade žene navode da se smatraju „premladima za preuzimanje uloge bolesnice", nisu pripremljene na iznenadni nastup bolesti niti je pripremljena njihova mreža podrške. U tim brzim, promjenjivim, ranim stadijima mlade su žene opisale zahtjeve i dodatne napore za nošenjem s višestrukim stresorima i izostanak sličnih prethodnih iskustava u životu iz kojih bi crpile snagu. Imaju osjećaj gubitka kontrole i „uhvaćenosti” u sustav koji je diktirao uvjete. Doživljaj „uhvaćenosti” u sustav može biti dodatno razumijevan i u vidom ograničenog prethodnog iskustva s bolešću i (dužim) bolničkim liječenjem. ${ }^{5,35}$ Apostrofiraju da je oboljenje za mnoge žene često i prvi ulazak u zdravstveni sustav (drugačiji od iskustva poroda i manjih zdravstvenih poteškoća), što može predstavljati dodatnu poteškoću u procesu prilagodbe. ${ }^{36}$

Provedene studije ukazuju na to da mlade žene, u usporedbi sa starijima, imaju veće poteškoće psihosocijalne prilagodbe na rak dojke. One iskazuju nižu kvalitetu života i više depresivnih simptoma. ${ }^{37-40}$ Niža kvaliteta života bila je povezana s problemima u partnerskoj vezi, problemima povezanima s područjem seksualnosti i slikom o vlastitom tijelu, izostankom tri mjeseca uobičajenih aktivnosti poslije dijagnoze i strategijama suočavanja. ${ }^{6} \mathrm{U}$ istraživanju ${ }^{41}$ oboljelih žena svih dobi, osim prethodnog iskustva psihološkog tretmana, mla- đa dob te izostanak kvalitetnog partnerskog odnosa prepoznati su i kao prediktori depresije i anksioznosti po završetku tretmana liječenja. Izazovi prilagodbe, i po završenom tretmanu, reflektirali su se u područjima anksioznosti i depresije, tjelesnog izgleda i seksualnosti, zabrinutosti o dugoročnim posljedicama tretmana liječenja te straha od recidiva. ${ }^{42}$

\section{Rak dojke kao rizik za narušeno reproduktivno zdravlje}

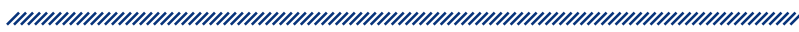

Mlade žene iskazuju jedinstvenu zabrinutost povezanu s dugoročnom toksičnošću adjuvantske terapije i očuvanjem reproduktivnog zdravlja, $i$ to u pogledu potencijalne neplodnosti, trudnoće i dojenja te kontracepcije. lako nije očekivano da će menopauza nastupiti ranije kod žena koje su u dobi do 30 godina primale kemoterapiju, u dobi od 35 godina rizik je veći i iznosi oko $18 \%$, dok je u dobi od 40 godina rizik oko $40 \% .{ }^{33}$ Prijetnja zadržavanju fertilnog statusa mladim ženama nije bila povezana samo sa željom za rođenjem djece, nego je percipirana i kao mogući gubitak određenih obilježja ženstvenosti te izostanak izbora i kontrole u ovom području života. ${ }^{43}$ Očuvanje fertiliteta doživljavale su i kao sekundarno po važnosti u odnosu na preživljenje, a razina zabrinutosti o plodnosti varirala je između sudionica. Ovisila je o osobnim okolnostima, vrijednostima i očekivanjima. Sudionice koje su pokušavale zasnovati obitelji bile su ujedno više i one koje su izjavljivale da je očuvanje fertiliteta utjecalo i na njihove odluke o tretmanu..$^{15,43}$

Dostupne empirijske spoznaje navode da mlade žene strahuju u pogledu trudnoće nakon liječenja, i to u smislu trudnoće kao dodatnog stimulatora koji bi mogao potaknuti recidiv bolesti; smanjene mogućnosti praćenja promjena u dojki uslijed promijenjene žljezdane strukture tijekom trudnoće; rođenja djeteta s teškoćama u razvoju i prijenosa nasljednih gena malignog oboljenja na dijete. ${ }^{17,44}$ lako plodnost može biti potencijalno reducirana, empirijske spoznaje navode da trudnoća nakon tretmana raka dojke ne povećava rizik recidiva bolesti. ${ }^{45-46}$ Sugerira se trudnoću odgoditi unutar tri godine od dijagnoze raka dojke, s obzirom na to da je recidiv bolesti najčešći u tom periodu. ${ }^{15,17}$ Kada je riječ o dojenju nakon iskustva liječenja, mlade žene oblikuju razloge za dojenje uz brojne koristi koje dojenje ima 
za dijete, društvena očekivanja i želju za stjecanjem takvog iskustva. ${ }^{17}$ Ipak, neke operacije i tretmani mogu ograničiti ili reducirati laktaciju (uslijed mastektomije i radioterapije), no dojenje je uglavnom nakon tretmana liječenja moguće i onda kada je riječ samo o jednoj dojci. Sudionice dojenje jednom dojkom nakon tretmana liječenja povezuju s poteškoćama smanjene laktacije, fizičkom boli i iscrpljenošću. ${ }^{47}$

Nekim mladim ženama roditeljstvo je značilo i zatvaranje jednog životnog razdoblja i početak novog te tada to opisuju u terminima poput „zatvaranje knjige o bolesti”. ${ }^{17} \mathrm{~S}$ druge strane, $\mathrm{u}$ istom istraživanju navodile su anksioznost i određene moralne dileme po pitanju planiranja potomstva, s obzirom na percipiranu ugroženost vlastitog životnog vijeka. ${ }^{17}$ Društveno pripisana uloga majčinstva može potencijalno objasniti tu anksioznost koju mlade žene osjećaju i tada je važno istaknuti potrebu za dubljim, osobnijim validiranjem iskustva bolesti umjesto iscrpljivanja očekivanjima i uvjerenjima koja su vrijedila u periodu prije oboljenja. ${ }^{17}$

\section{Obitelj i partnerstvo: Promjene obiteljske rutine i potencijal za partnerski rast}

Kod mladih žena posebno je vidljiva borba između nastojanja ispunjavanja zahtjeva postavljenih protokolom liječenja i usmjerenosti na vlastite potrebe te brige o djeci i pokušaja zadržavanja dosadašnje obiteljske rutine. ${ }^{49} \mathrm{U}$ istraživanju su evocirale period liječenja kao vrijeme kada su intenzivno morale biti jake zbog obitelji. ${ }^{49}$ Navedeno je bilo posebno otežano u periodima aktivnog tretmana liječenja, često praćenog tjelesnom slabošću uslijed terapijskih nuspojava i hospitalizacija. Mladim ženama bilo je zahtjevno prihvatiti promijenjeni fokus skrbi, tj. primarnu orijentiranost ka zadovoljavanju potreba djece usmjeriti na prioritet skrbi o vlastitom zdravlju. Također, navode strah kako neće biti nazočne prilikom njihova odrastanja. ${ }^{48,50}$ Neke od obiteljskih strategija nošenja s bolešću odnosile su se na pokušaj uspostavljanja kontrole u novonastalim okolnostima, zadržavanje i nadalje uobičajenog života obitelji uz povećane zahtjeve za fleksibilnošću, ali, na primjer, i uskraćivanje informacija o bolesti kolegama i prijateljima, kako bi i dalje imali dio života u kojem bolest nije u primarnom fokusu. ${ }^{12}$
Tijekom perioda liječenja bilo im je emocionalno zahtjevno pomagati djeci u nošenju s njihovom bolešću te pričati s njima o bolesti, dok su one žene koje su s djecom o navedenim temama razgovarale kao najčešće razloge za razgovor navodile želju za zadržavanjem djetetova povjerenja i komunikacije. ${ }^{13}$ Poteškoće u komunikaciji bile su nazočne i u partnerskom odnosu..$^{50}$ Većini sudionica bilo je problematično razgovarati s partnerom o životu i budućnosti ako one preminu te o bolesti i strahovima povezanima s bolešću. Svoje je partnere kao emocionalno nedostupne i sklone izbjegavanju komunikacije okarakteriziralo $35 \%$ žena. Nadalje, poteškoće u partnerskom odnosu reflektirale su se i na seksualni život, promijenjenu obiteljsku dinamiku te financijsku stabilnost, no iskustvo oboljenja pridonijelo je i kvalitetnijem partnerskom odnosu. ${ }^{13}$ Partneri su iskazivali povećanu partnersku bliskost po izlječenju i odbacivali tezu o povećanoj stopi razvoda braka. ${ }^{51,52}$

\section{Odstupanje od "normalnog" tjelesnog izgleda i promjene $u$ seksualnom funkcioniranju}

Uslijed terapijskih intervencija u procesu liječenja žene su znatno izložene potencijalnim promjenama tjelesnog izgleda, i to najčešće u vidu gubitka ili promijenjenog oblika jedne ili dvije dojke, ožiljaka od operacija i promjena na koži. S obzirom na to da su ženskim grudima pripisani simboli ženstvenosti, majčinstva i seksualne privlačnosti, odstupanje od „normalnog” izgleda grudi može imati brojne implikacije na ženino poimanje sebe, sliku o sebi, psihološku dobrobit i seksualnost. Postojeći sociokulturalni diskurs utječe na konstruiranje razumijevanja seksualnosti i ženstvenosti te postavlja estetske i vrijednosne kriterije „uspješnog, idealnog i lijepog”, odnosno „neuspješnog, neprivlačnog i lošeg”. 53 Stoga je važna polazišna osnova u razumijevanju izazova s kojima se suočavaju mlade žene sadržana i u svijesti o kulturološki kreiranoj socijalnoj zbilji u čijem se zrcalu one ogledaju. Operativni zahvati, djelomična ili totalna mastektomija, mogu trajno promijeniti tijelo žene i pridonijeti poimanju vlastite ženstvenosti izvan okvira ,normalne”. ${ }^{11,53}$ Žene s izrazito izraženom asimetrijom imale su osjećaj veće stigmatiziranosti i manje su iskazivale nepromijenjeno ili poboljšano zdravlje nakon 
tretmana u usporedbi sa ženama koje su doživjele minimalnu asimetriju. 0 osjećaju stigmatiziranosti mlađe su žene izvještavale više nego one u dobi od 51 do 60 godina. ${ }^{54}$

One žene koje su razvile negativnu percepciju tijela uslijed oboljenja ujedno su i one koje iskazuju veće nezadovoljstvo svojim izgledom, percipiraju gubitak ženstvenosti i tjelesnog integriteta, nerado gledaju svoje nago tijelo, imaju osjećaj manje seksualne atraktivnosti i nezadovoljne su operacijskim ožiljcima. ${ }^{55}$ Mlađa je dob, uz hormonsku terapiju i slabije seksualno funkcioniranje prije tretmana, bila i najznačajniji faktor koji pridonosi seksualnim poteškoćama nakon tretmana. ${ }^{56}$

Nadalje, razumijevanje seksualnosti u kontekstu oboljenja od raka dojke nesagledivo je samo kroz aspekt tjelesnog i neodvojivo je od ženinog intrapsihičkog iskustva, kao i od utjecaja društvene konstrukcije seksualnosti i ženstvenosti. ${ }^{53}$ Promjene u seksualnom funkcioniranju žena tijekom i nakon liječničkog tretmana najčešće su povezane sa smetnjama seksualnog uzbuđenja, lubrikacijom, doživljavanjem orgazma, seksualnom željom i užitkom. ${ }^{20,53}$ Kod seksualno aktivnih žena, veće poteškoće povezane sa slikom o tijelu odnosile su se na mastektomiju i moguću rekonstrukciju, gubitak kose uslijed kemoterapije, zabrinutost oko tjelesne težine, lošije mentalno zdravlje, niže samopouzdanje i osjećaj partnerskog nerazumijevanja. Od 360 seksualno aktivnih žena, polovica ( $52 \%$ ) ih je navela da ima male probleme u dva ili više područja seksualnog funkcioniranja ili ozbiljni problem u najmanje jednom području $(28 \%) .^{55}$

\section{Promjene u socijalnoj mreži}

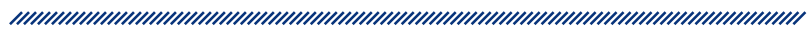

Oboljenje unosi i promjene u postojeću socijalnu mrežu mladih žena. Ona je manje stabilna i uspostavljena u odnosu na starije žene. ${ }^{35} \mathrm{U}$ prilog navedenoj tezi govori i istraživanje ${ }^{25}$ čiji autori zaključuju da je manje izvjesno da će se socijalna mreža starijih sudionica ( $\geq 51$ god.) smanjiti u usporedbi s mrežom mladih sudionica. Starije sudionice izvijestile su o snažnijem prijateljstvu s članovima svoje socijalne mreže (s visokim udjelom članova obitelji) i znatno su više bile one koje su zadržale mrežu članova u usporedbi s mladim ženama. Jedno od potencijalnih objašnjenja moguće je pronaći u okvirima socioemocionalne selektivne teorije, prema kojoj oso- be koje percipiraju ograničenje vremena u budućnosti postaju selektivnije oko društvenih veza te preferiraju kontakte koji im omogućavaju emocionalno važna i zadovoljavajuća iskustva, ${ }^{25}$ što posebno mogu koristiti mlade žene.

Mlade žene rangirale su informacijsku i psihološku pomoć važnijom u odnosu na starije i pritom iskazale manje zadovoljstvo primljenim informacijama. ${ }^{57}$ One ističu izostanak dostupnih programa podrške kreiranih u skladu s njihovim specifičnim potrebama. ${ }^{24,58}$ Percipiraju najkorisnijom emocionalnu podršku bračnog partnera, obitelji i prijatelja, ${ }^{12,24}$ što je usporedivo i s drugim pacijentima oboljelima od različitih vrsta malignih oboljenja. ${ }^{32}$ Kvalitetna socijalna podrška povezana je s poboljšanim zdravstvenim ishodima. ${ }^{23}$ Rezultati kohortne studije ${ }^{26} \mathrm{u}$ kojoj je sudjelovalo 336 žena upućuju na to da je i veličina socijalne mreže bila povezana s većom emocionalnom i instrumentalnom podrškom. Nadalje, veća emocionalna podrška bila je povezana s procjenom boljega mentalnog zdravlja, dok je dostupnost veće instrumentalne podrške bila povezana s lošijom tjelesnom dobrobiti. S druge strane, neadekvatna razina socijalne podrške može dodatno štetiti oboljelima i povećati broj psihosocijalnih poteškoća. ${ }^{36}$ Mlade su žene iskazivale naglašenu motivaciju u izgradnji novih odnosa kroz uključenost u vršnjačke mreže podrške oboljelih tijekom procesa liječenja. Nastojale su redefinirati odnose s osobama u svojoj socijalnoj mreži podrške, kako bi ispunile svoje potrebe (npr. tražile su od roditelja uslugu prijevoza), uz pokušaj zadržavanja vlastite autonomije (ostajući živjeti u stanu u kojem do sada žive). ${ }^{59}$

\section{Umjesto zaključka: Kako pomagati i što pomaže mladim oboljelim ženama?}

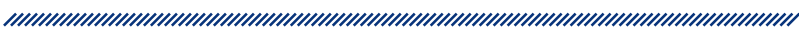

Osiguravanje učinkovite psihosocijalne podrške tijekom liječenja kod mladih žena težit će zadovoljavanju potreba i odgovaranju na specifične izazove s kojima su suočene po oboljenju. Ipak, prvi korak u pružanju takve podrške polazi od usvajanja potrebnih znanja i vještina zdravstvenih stručnjaka o psihosocijalnim potrebama ove skupine; u prvom redu liječnika onkologa, psihijatara, psihologa i medicinskih sestara. Od njih mlade žene očekuju informacije o prirodi bolesti, planiranom 
protokolu liječenja i psihosocijalnim posljedicama oboljenja. Pružati pravodobne i cjelovite informacije tijekom čitavog procesa liječenja znači kontinuirano zadovoljavati potrebu za informacijskom podrškom, koja je ovoj populaciji osobito važna. Područja od posebnog informacijskog interesa odnose se na reproduktivno zdravlje, od potencijalne neplodnosti do informacija o kontracepciji i trudnoći poslije bolesti, ${ }^{11,18,43}$ seksualno funkcioniranje, ${ }^{19}$ prenatalnu edukaciju i dostupnost poslijeporođajne podrške. ${ }^{47}$ Upravo je rasprava o reproduktivnom i seksualnom zdravlju neadekvatno komunicirana s pacijenticama, ${ }^{19}$ koje sugeriraju da bi medicinsko osoblje trebalo inicirati ranu diskusiju o tretmanskim mogućnostima očuvanja fertiliteta, i u vrijeme dijagnoze i nakon tretmana. ${ }^{5}$

Osim informacijskog savjetovanja, i druge psihosocijalne intervencije (pod vodstvom psihologa, psihijatara i socijalnih radnika) dosljedno rezultiraju pozitivnim ishodima u pogledu emocionalne i funkcionalne prilagodbe te upravljanja simptomima povezanima $\mathrm{s}$ liječenjem i bolesti. Dva modela tretmana najviše su istraživana i primjenjivana: kognitivno-bihevioralni (upravljanje stresom, vještine kognitivnog suočavanja) i suportivno-ekspresijski (fokusiran na ekspresiju i proradu emocija). ${ }^{2}$ Nadalje, mladim je ženama od pomoći bilo i pisanje dnevnika i usmjeravanje na aktivnosti koje nisu povezane s bolešću i liječenjem ${ }^{35}$ te su željele umrežavanje s drugim ženama usporedne dobi s iskustvom oboljenja i izlječenja. ${ }^{24}$ Pružati podršku u roditeljstvu i partnerstvu ${ }^{13}$ značilo bi: a) pomoći pacijentici i njezinoj obitelji u pridobivanju informacija o medicinskoj, operacijskoj i tretmanskoj proceduri te donošenju odluke o tretmanu nakon odmjeravanja svih prednosti i nedostataka; b) kreirati sigurnu mrežu za izražavanje pacijentičinih osjećaja i osjećaja članova obitelji povezanih s inicijalnim i dugoročnim tretmanom; c) pomoći parovima i obitelji osvijestiti i podijeliti strahove povezane s oboljenjem te d) poticati normalizaciju i validirati emocionalno iskustvo svakog člana obitelji, e) „dati” dopuštenje obitelji za otvoreni razgovor o osjećajima i strahovima koje imaju jedni za druge.

U pogledu seksualnog funkcioniranja partnera, a u vidom spoznaje da je jedan od najdosljednijih i najvažnijih prediktora seksualnog zdravlja kod žena oboljelih od raka dojke kvaliteta partnerskog odnosa, ${ }^{53}$ profesionalnim je pomagačima to iznimno važna smjernica u kreiranju i razvijanju programa podrške. Jedan od najučinkovitijih oblika intervencije namijenjen partnerima psihoedukativni je pristup s elementima seksualne psihoterapije. ${ }^{60}$ Prijedlog je u radu obuhvatiti i usmjeriti se i na sljedeće aspekte: 1) u fazi planiranja tretmana liječenja provoditi savjetovanje o mogućim utjecajima tretmana na seksualnu aktivnost, sliku o tijelu, seksualno funkcioniranje i partnerske odnose; 2) osiguravati kontinuiranu mogućnost razgovora sa zdravstvenim osobljem; 3) uspostaviti i provoditi programe usmjerene pomoći ženama u procesu prilagodbe na „promijenjenu (seksualnu) sebe”, a posebno onima koje imaju nisko samopouzdanje, probleme mentalnog zdravlja i poteškoće u komunikaciji s partnerom te 4) razvijati programe namijenjene poboljšavanju ili zadržavanju učinkovite komunikacije i pozitivnih seksualnih odnosa partnera. ${ }^{55}$

S obzirom na to da istraživanja upućuju na manjak dostupnih programa podrške kreiranih u skladu s potrebama ove populacije, ${ }^{9,58}$ u provedbi postojećih ili pri implementaciji novih programa važno je sadržaj tih programa prilagoditi njihovim jedinstvenim potrebama. Young Survival Coalition (YSC) ${ }^{61}$ jedna je takva mreža. U Hrvatskoj bi to bio Centar za psihološku pomoć Udruge SVE za NJU. Neke od psihosocijalnih potreba oboljele mlade žene mogle bi se zadovoljiti u sklopu četiri glavna programa: psihološkog tretmana, savjetovališta, edukacijsko-terapijskih programa i smještaja u Centru. ${ }^{62}$ Osim izravnog rada s oboljelim ženama i njihovim obiteljima, osobito se važnim čini razvijati i dodatno unaprijediti istraživanja u ovom području. Empirijski prioriteti odnose se na teme donošenja zajedničkih tretmanskih odluka, vrste tretmana, slike o tijelu, straha od recidiva i palijativne skrbi te posttraumatskog rasta. ${ }^{63,64}$ Iščitavajući postojeće radove, tema populacije mladih oboljelih žena i imanentnih im izazova ostaje i dalje empirijski zanemarena, uz određena metodološka ograničenja (mali uzorci, retrospektivne studije, izostanak kontrolne grupe), što u budućim istraživanjima valja unaprijediti.

\section{Referencije}

1. Naaman S, Radwan K, Johnson S. Coping with Early Breast-Cancer: Couple Adjustment Processes and CoupleBased Intervention. Psychiatry. 2009; 27(4): 321-345.

2. Compas BE, Luecken L. Psychological Adjustment to Breast Cancer. American Psychological Society. 2002; 11(3): 111-114.

3. National Cancer Institute, Surveillance, Epidemiology, and Results Program. Cancer Stat Facts: Breast Cancer. Dostupno na https://seer.cancer.gov/statfacts/html/breast.html (pristupljeno 18.4.2018.). 
4. Hrvatski zavod za javno zdravstvo, Registar za rak. Incidencija raka u Hrvatskoj 2015. Bilten 40. Zagreb, 2018. Dostupno na: https://www.hzjz.hr/wp-content/uploads/2018/03/Bilten_2015_rak_final.pdf (pristupljeno 18.4.2018.).

5. Dunn J, Steginga S. Young women's experience of breast cancer: defining young and identifying concerns. Psycho-Oncology. 2000; 9: 137-146.

6. Avis NE, Crawford S, Manuel J. Quality of Life Among Younger Women With Breast Cancer. Journal of Clinical Oncology. 2005; 23(15): 3322-3330.

7. Arndt V, Merx H, Sturmer T, Stegmaier C, Ziegler $\mathrm{H}$, Brenner $\mathrm{H}$. Age-specific detriments to quality of life among breast cancer patients one year after diagnosis. European Journal of Cancer. 2004; 40(5): 673-680.

8. Nass SJ, Beaupin LK, Demark-Wahnefried W, Fasciano K, Ganz PA, Hayes-Lattin B, Hudson MM, Nevidjon B, Oeffinger KC, Rechis R, Richardson LC, Seibel NL, Smith AW. Identifying and Addressing the Needs of Adolescents and Young Adults With Cancer: Summary of an Institute of Medicine Workshop. Oncologist. 2015; 20(2): 186-195.

9. Ahmad S, Fergus K, McCarthy M. Psychosocial issues experienced by young women with breast cancer: the minority group with the majority of need. Current Opinion in Support Palliat Care. 2015; 9: 271-278.

10. Ruddy KJ, Greaney ML, Sprunck-Harrild K, Meyer ME, Emmons KM, Partridge, AH. Young Women with Breast Cancer: A Focus Group Study of Unmet Needs. Journal of Adolescent Young Adult Oncolology. 2013; 2(4): 153-160.

11. Adams E, McCann L, Richardson A, Stark D, Watson E, Hubbard G. The experience, needs and concerns of younger women with breast cancer: a meta-ethnography. Psycho-Oncology. 2011; 20: 851-861.

12. Coyne E. The Strengths and Resources Young Women and their Family Members use during Treatment for Breast Cancer. Doktorska disertacija. Brisbane: Griffith University. School of Nursing and Midwifery; 2011.

13. Walsh SR, Manuel JC, Avis NE. The Impact of Breast Cancer on Younger Women's Relationships With Their Partner and Children. Families Systems and Health. 2005; 23(1): 80-93.

14. Northouse LL. Breast cancer in younger women: Effects on interpersonal and family relations. Journal of the National Cancer Institute Monographs. 1994; 16: 183-190.

15. Gorman JR, Usita P, Madlensky L, Pierce JP. Young Breast Cancer Survivors: Their Perspectives on Treatment Decisions and Fertility Concerns. Cancer Nursing. 2011; 34(1): 32-40.

16. Partridge AH, Gelber S, Peppercorn J, Sampson E, Knudsen K, Laufer M, Rosenberg R, Przypyszny M, Rein A, Winer EP. Web-Based Survey of Fertility Issues in Young Women With Breast Cancer. Journal of Clinical Oncology. 2004; 22(20): 4174-4183.

17. Connell SE, Patterson C, Newman B. A qualitative Analysis of Reproductive Issues Raised by Young Australian Women with Breast Cancer. Health Care of Women International. 2006; 27(1): 94-110.
18. Duffy CM, Allen SM, Clark MA. Discussion Regarding Reproductive Health for Young Women With Breast Cancer Undergoing Chemotherapy. Journal of Clinical Oncology. 2005; 23(4): 766-773.

19. Wang Y, Chen L, Ruan JY, Winson YC. Discussions about reproductive and sexual health among young adult survivors of cancer. Cancer Medicine. 2016; 5(6): 1037-1046.

20. Bakht S, Najafi S. Body image and sexual dysfunctions: comparison between breast cancer and healthy women. Procedia Social and Behavioral Sciences. 2010; 5: 14931497.

21. Burwell SR, Douglas Case L, Kaelin C, Avis NE. Sexual Problems in Younger Women After Breast Cancer Surgery. Journal of Clinical Oncology. 2006; 24(18): 2815-2821.

22. Schover LR. Sexuality and body image in younger women with breast cancer. Journal of the National Cancer Institute Monographs. 1994; 16: 177-182.

23. Chou AF, Stewart SL, Wild RC, Bloom, JR. Social Support and Survival in Young with Breast Carcinoma. Psychooncology. 2012; 21(2): 125-133.

24. Snyder KA, Pearse W. Crisis, Social Support, and the Family Response: Exploring the Narratives of Young Breast Cancer Survivors. Journal of Psychosocial Oncology. 2010; 28(4): 413-431.

25. Ashida S, Palmquist AEL, Basen-Engquist K, Singletary SE, Koehly, LM. Changes in Female Support Network Systems and Adaptation After Breast Cancer Diagnosis: Difeferences Between Older and Younger Patients. The Gerontologist. 2009; 49(4): 549-559.

26. Bloom JR, Stewart SL, Johnston M, Banks P, Fobair P. Sources of support and the physical and mental well-being of young women with breast cancer. Social Science \& Medicine. 2001; 53: 1513-1524.

27. Lantz PM, Booth KM. The social construction of the breast cancer epidemic. Social Science \& Medicine. 1998; 46(7): 907-918.

28. Ministarstvo zdravstva i socijalne skrbi. Nacionalni program ranog otkrivanja raka dojke. Zagreb, 2006. Dostupno na: http://www.nzjz-split.hr/pdf/Rak_dojke7.pdf (pristupljeno 15.4.2018.).

29. Reyna C, Lee MC. Breast cancer in young women: special considerations in multidisciplinary care. Journal of Multidisciplinary Healthcare. 2014; 7: 419-429.

30. Gabriel CA, Domchek SM. Breast cancer in young women. Breast Cancer Research. 2010; 12(5): 2012.

31. Rosenberg R, Levy-Schwartz, R. Breast Cancer in Women Younger Than 40 Years. International Journal of Fertility and Women's Medicine. 2003; 48(5): 200-205.

32. Pahljina-Reinić R. Psihosocijalna prilagodba na rak dojke. Psihologijske teme. 2004; 13(1): 69-90.

33. Brennan M, French J, Houssami N, Kirk J, Boyages J. Breast cancer in young women. Australian Family Physician. 2005; 34(10): 851-855.

34. Ganz PA, Bower JE, Stanton, AL. Special Issues in Younger Women with Breast Cancer. U: Ganz, PA (ur.) Improving Outcomes for Breast Cancer Survivors: Perspectives 
on Research Challenges and Opportunities. New York: Breast Cancer Research Foundation \& Springer International Publishing; 2015: 9-21.

35. Coyne E, Borbasi S. Living the experience of breast cancer treatment: The younger women's perspective. Australian Journal of Advanced Nursing. 2009; 26(4): 6-13.

36. Ganz PA. Psychological and Social Aspects of Breast Cancer. Oncology. 2008; 22(6): 642-650.

37. Howard-Anderson J, Ganz PA, Bower JE, Stanton AL. Quality of Life, Fertility Concerns, and Behavioral Health Outcomes in Younger Breast Cancer Survivors: A Systematic Review. Oxford University Press. 2012; 104(5): 386-405.

38. Høyer M, Johansson B, Nordin K, Bergkvist L, Ahlgren J, Lidin-Lindqvist A, Lambe M, Lampic C. Health-related quality of life among women with breast cancer - a population-based study. Acta Oncologica. 2011; 50: 1015-1026.

39. Hopwood P, Haviland J, Mills J, Sumo G, Bliss JM. The impact of age and clinical factors on quality of life in early breast cancer: An analysis of 2208 women recruited to the UK START Trial (Standardisation of Breast Radiotherapy Trial). The Breast. 2007; 16: 241-251.

40. Kroenke $\mathrm{CH}$, Rosner B, Chen WY, Kawachi I, Colditz GA, Holmes MD. Functional Impact of Breast Cancer by Age at Diagnosis. Journal of Clinical Oncology. 2004; 22(10): 1849-1856.

41. Burgess C, Cornelius V, Love S, Graham J, Richards M, Ramirez A. Depression and anxiety in women with early breast cancer: five years observational cohort study. British Medical Journal. 2005; 330: 702-707.

42. Kornblith $A B$, Powell M, Regan MM, Bennett $S$, Krasner C, Moy B, Younger J, Goodman A, Berkowitz A,Winer E. Long-term psychosocial adjustment of older vs younger survivors of breast and endometrial cancer. Psycho-Oncology. 2007; 16: 895-903.

43. Penrose R, Beatty L, Mattiske J., Koczwara B. Fertility and cancer-a qualitative study of Australian cancer survivors. Support Care Cancer. 2012; 20: 1259-1265.

44. Schover LR. Motivation for Parenthood After Cancer: A Review. Journal of the National Cancer Institute Monographs. 2005; 34: 2-5.

45. Duffy CM, Allen SM. Medical and Psychosocial Aspects of Fertility After Cancer. Journal of Clinical Oncology. 2009; 15(1): 27-33.

46. Rippy EE, Karat IF, Kissin MW. Pregnancy after breast cancer: the importance of active counselling and planning. Breast. 2009; 18: 345-350.

47. Gorman JR, Usita PM, Madlensky L, Pierce JP. A qualitative investigation of breast cancer survivors' experience with breastfeeding. Journal of cancer survivorship. 2009; 3(3): 181-191.

48. Adams E, Dell P. Being a „good mother": A discourse analysis of women's experiences of breast cancer and motherhood. The Psychology of Women Section Review. 2008; 10(1): 3-12.

49. Coyne E, Borbasi S. Holding it all together: Breast cancer and its impact on life for younger women. Contemporary
Nurse: a Journal for the Australian Nursing Profession. 2006; 23(2): 157-169.

50. Fergus KD, Gray RE. Relationship vulnerabilities during breast cancer: patient and partner perspectives. PsychoOncology. 2009; 18: 1311-1322.

51. Dorval M, Guay S, Mondor M, Mâsse B, Falardeau M, Robidoux A, Deschênes L, Maunsell E. Couples Who Get Closer After Breast Cancer: Frequency and Predictors Investigation. Journal of Clinical Oncology. 2005; 23(15): 3588-3596.

52. Dorval M, Maunsell E, Taylor-Brown J, Kilpatrick M. Marital Stability After Breast Cancer. Journal of the National Cancer Institute. 1999; 91(1): 54-59.

53. Emilee G, Ussher JM, Perz J. Sexuality after breast cancer: A review. Maturitas. 2010; 66: 397-407.

54. Waljee JF, Hu ES, Ubel PA, Smith DM, Newman LA, Alderman AK. Effect of Esthetic Outcome After Breast-Conserving Surgery on Psychosocial Functioning and Quality of Life. Journal of Clinical Oncology. 2008; 26(20): 3331-3337.

55. Fobair P, Stewart SL, Chang S, D’Onofrio C, Banks PJ, Bloom JR. Body image and sexual problems in young women with breast cancer. Psychooncology. 2006; 15(7): 579-597.

56. Harirchi I, Montazeri A, Bidokhti FZ, Mamishi N, Zendehdel K. Sexual function in breast cancer patients: a prospective from Iran. Journal of Experimental \& Clinic Cancer Research. 2012; 31(1): 20-31.

57. Kerr J, Engel J, Schlesinger-Raab A, Sauer H, Hölzel1 D. Communication, quality of life and age: Results of a 5-year prospective study in breast cancer patients. Annals of Oncology. 2003; 14: 421-427.

58. Ahmed K, Marchand E, Williams V, Coscarelli, A, Ganz PA. Development and Pilot Testing of a Psychosocial Intervention Program for Young Breast Cancer Survivors. Patient Education and Counseling. 2016; 99(3): 414-420.

59. Froude C, Rigazio-DiGilio, Donorfio L, Bellizzi K. Contextualizing the Youth Adult Female Breast Cancer Experience: Developmental, Psychosocial, and Interpersonal. The Qualitative Report. 2017; 22(6): 1488-1510.

60. Taylor S, Harley C, Ziegler L, Brown J, Velikova G. Interventions for sexual problems following treatment for breast cancer: a systematic review. Breast Cancer Research and Treatment. 2011; 130: 711-724.

61. Young Survival Coalition's (YSC). Dostupno na https:// www.youngsurvival.org/ (pristupljeno 2.5.2018.).

62. Vukota Lj, Mužinić L. Sustavna psihološka i psihosocijalna podrška ženama oboljelima od raka dojke. Journal of Applied Health Sciences $=$ Časopis za primijenjene zdravstvene znanosti. 2015; 1(2): 97-106.

63. Fernandes-Taylor S, Adesoye T, Bloom JR. Managing psychosocial issues faced by young women with breast cancer at the time of diagnosis and during active treatment. Curr Opin Support Palliat Care. 2015; 9(3): 279-284.

64. Boyle CC, Stanton AL, Ganz PA. Posttraumatic growth in breast cancer survivors: Does age matter? Psychooncology. 2017; 26(6): 800-807. 


\section{PSYCHOSOCIAL ASPECTS OF YOUNG WOMEN AFFECTED WITH BREAST CANCER}

1 Anita Džombić

1 Center for Social Welfare Ivanić-Grad

\section{Abstract}

Psychosocial aspects of breast cancer are found in young women within their specific developmental stages. Breast cancer in young women, in contrast to older women, is primarily related to the challenges in their careers, relationships, families, child care, reproductive health, sexuality, as well as to their own body image. Although a single definition of such population in psychooncological literature is missing, the women in question are in the fertile, premenopausal stages of their lives, and are in the age range of up to 50 years of age. Contemporary empirical knowledge has been indicating that they are perceived as "too young to take on the role of cancer patients", they have greater difficulties in psychosocial adjustment to their illness and overall experience lower quality of life. They have a need for comprehensive information support in due time, while the discussion about their reproductive health, prenatal education and sexuality is of crucial importance at the very beginning of their treatment. These women would like to emphasize that there is an inadequate number of support programs targeted at this population and they clearly demonstrate readiness to participate in peer support networks. In accordance with the aforementioned, this paper seeks to show the specificities of psychosocial needs and issues these young women have due to their illness. 